\title{
Nucleus-Specific Chloride Homeostasis in Rat Thalamus
}

\author{
Daniel Ulrich and John R. Huguenard \\ Department of Neurology and Neurological Sciences, Stanford University School of Medicine, Stanford, California 94305
}

Synchronous thalamic network activity occurring during slow wave sleep and paroxysmal discharges critically depends on the ability of thalamocortical relay cells and inhibitory neurons of the nucleus reticularis thalami (nRt) to fire bursts of action potentials. Inhibitory synaptic potentials (IPSPs) originating from $\mathrm{nRt}$ cells are crucial in deinactivating T-channels and thus promoting burst firing in relay cells, but the functional role of intra-nRt IPSPs is less well understood. A major factor that regulates the net effects of IPSP generation is the chloride equilibrium potential $\left(E_{\mathrm{Cl}}\right)$. Here we applied the perforated patch-clamp technique, using the cation-selective ionophore gramicidin to assess the reversal potential of chloride in $\mathrm{nRt}$ and relay cells in brain slices. We found that the reversal potential of GABA-induced membrane currents ( $\left.E_{\mathrm{GABA}}\right)$ was significantly more hyperpolarized in relay $(-81 \pm 2.6 \mathrm{mV})$, as compared with $\mathrm{nRt}$ cells $(-71 \pm 2.5 \mathrm{mV})$. $E_{\mathrm{GABA}}$ was not significantly different from the reversal potential of evoked IPSCs ( $E_{\text {IPSC }} ;-82 \pm 4.4 \mathrm{mV}$ ) in relay cells. In both relay and reticular neurons the chloride gradient was collapsed partially by the chloride cation cotransport blocker furosemide, suggesting an active chloride extrusion mechanism in thalamic neurons. Given the relatively hyperpolarized resting potentials (approximately $-70 \mathrm{mV}$ ) reported for $\mathrm{nRt}$ and relay cells during in vitro thalamic oscillations, we conclude that under these conditions GABA $_{A}$ IPSPs lead to significant hyperpolarization in relay cells. By contrast, intra-nRt inhibition essentially would be shunting, i.e., would produce minimal membrane polarization but still could reduce the amplitude of excitatory events.

Key words: GABA; IPSP; somatosensory; nRt; perforated patch; inhibition; chloride transport
Synchronous intrathalamic network oscillations occur during slow wave sleep, anesthesia, and paroxysmal discharges (Steriade et al., 1993). During these events mutually connected thalamocortical relay cells and inhibitory neurons of the nucleus reticularis thalami (nRt) fire bursts of action potentials that are generated by low-threshold calcium spikes. In addition, via local axon collaterals, nRt cells form an interconnected network of inhibitory neurons in rodents (Spreafico et al., 1988; Cox et al., 1996). Dendrodendritic synapses may contribute to intra-nRt inhibition in cats and monkeys (Deschênes et al., 1985; Williamson et al., 1994). IPSPs mediated by GABA type A and B receptors are essential for repriming low-threshold calcium channels for burst firing in relay cells (Crunelli et al., 1988; von Krosigk et al., 1993; Huguenard and Prince, 1994a). Indirect measurements suggest that the reversal potential for $\mathrm{Cl}^{-}$-dependent, $\mathrm{GABA}_{\mathrm{A}}$ receptor-mediated IPSPs $\left(E_{\text {IPSP }}\right)$ in relay cells is surprisingly hyperpolarized (Huguenard and Prince, 1994a; Bal et al., 1995a). This would make these IPSPs very efficient in deinactivating T-channels in thalamic cells.

As yet, the chloride reversal potential in $\mathrm{nRt}$ cells has not been determined accurately. Microelectrode recordings from $\mathrm{nRt}$ cells revealed a reversal potential of GABA currents $\left(E_{\mathrm{GABA}}\right)$, which is depolarizing (Spreafico et al., 1988), shunting (McCormick and Prince, 1986), or hyperpolarizing (Bal and McCormick, 1993). However, none of these reports was capable of determining the $\mathrm{GABA}_{\mathrm{A}}$ receptor-dependent chloride reversal potential $\left(E_{\mathrm{Cl}}\right)$ accurately, because the recording technology most likely interfered

Received Dec. 17, 1996; revised Jan. 17, 1997; accepted Jan. 22, 1997.

This work was supported by National Institute of Neurological Disorders and Stroke Grants NS06477 and NS34774, the Pimley Research Fund, and the Schweizerische Stiftung für medizinisch-biologische Stipendien.

Correspondence should be addressed to Dr. Daniel Ulrich, Department of Neurology, Medical Center Room M030, Stanford University School of Medicine, Stanford, CA 94305.

Copyright (C) 1997 Society for Neuroscience $\quad 0270-6474 / 97 / 172348-07 \$ 05.00 / 0$ with the intracellular chloride activity (Kyrozis and Reichling, 1995). The effectiveness of intra-nRt IPSPs is a critical issue in intrathalamic oscillations. Whereas an intact thalamic circuitry is necessary to maintain oscillatory activity in vitro (von Krosigk et al., 1993), the surgically disconnected nRt (consisting of interconnected inhibitory cells) is capable of acting as a pacemaker of spindle waves in vivo (Steriade et al., 1987). Recent computer models of nRt support this finding by showing that assemblies of inhibitory cells can form temporally segregated clusters of bursting cells that self-sustain oscillatory activity (Golomb et al., 1994). However, a crucial parameter in this model is the reversal potential of the intra-nRt $\mathrm{GABA}_{\mathrm{A}}$ receptor-mediated IPSPs: hyperpolarizing IPSPs promote oscillatory activity, whereas shunting IPSPs tend to synchronize and silence the network (Golomb et al., 1994).

Therefore, in the present study the noninvasive perforated patch recording technique was used with the cation-specific ionophore gramicidin, which allowed for the determination of $E_{\mathrm{Cl}}$ in relay and nRt cells. Our findings suggest different functional roles of intra-nRt and nRt relay IPSPs during thalamic oscillations and other circuit activities.

\section{MATERIALS AND METHODS}

Tissue preparation. Sprague Dawley rats of either sex, postnatal days $9-12$, were anesthetized with pentobarbital $(50 \mathrm{mg} / \mathrm{kg}$, i.p.) and decapitated. The whole brain was removed and transferred into ice-cold solution containing (in mM): 234 sucrose, 11 glucose, $24 \mathrm{NaHCO}_{3}, 2.5 \mathrm{KCl}$, $1.25 \mathrm{NaH}_{2} \mathrm{PO}_{4}, 10 \mathrm{MgSO}_{4}$, and $0.5 \mathrm{CaCl}_{2}$, equilibrated with $95 \% \mathrm{O}_{2} / 5 \%$ $\mathrm{CO}_{2}$. Horizontal slices of $200 \mu \mathrm{m}$ thickness were cut with a vibratome (TPI, St. Louis, MO) and incubated at $32^{\circ} \mathrm{C}$ in physiological saline containing (in mM): $126 \mathrm{NaCl}, 26 \mathrm{NaHCO}_{3}, 2.5 \mathrm{KCl}, 1.25 \mathrm{NaH}_{2} \mathrm{PO}_{4}, 2$ $\mathrm{MgCl}_{2}, 2 \mathrm{CaCl}_{2}$, and 10 glucose, equilibrated with $95 \% \mathrm{O}_{2} / 5 \% \mathrm{CO}_{2}$ for at least $1 \mathrm{hr}$ before recording (Huguenard and Prince, 1994a).

Electrophysiology. Slices were transferred into a perfusion chamber and superfused with physiological saline at $22^{\circ} \mathrm{C}$. Experiments were done under visual control with $40 \times$ Hoffman modulation optics (Sakmann et 
A

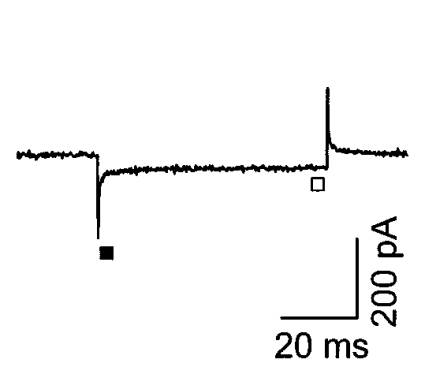

B

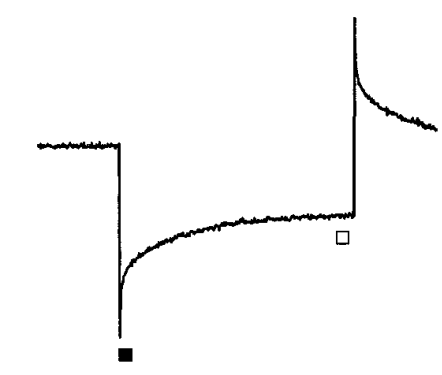

\section{C}

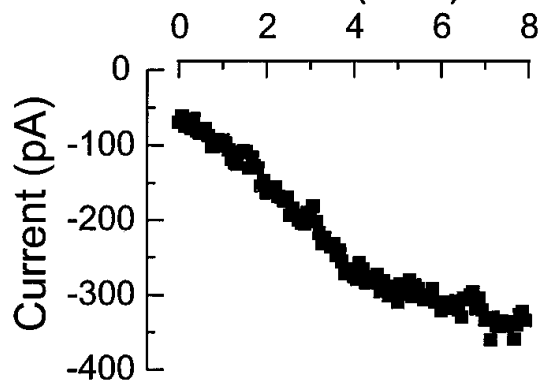

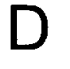

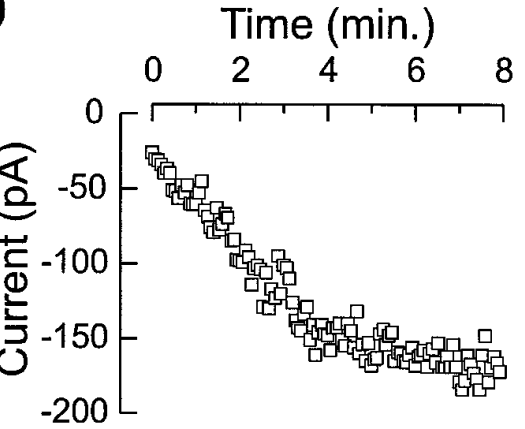

Figure 1. Perforated patch-clamp recording in a $\mathrm{nRt}$ cell. Shown are current responses to a $20 \mathrm{mV}$ hyperpolarizing voltage step after seal formation $(A)$ and 8 min thereafter $(B)$. Note the increase in amplitude of the instantaneous $(\square)$ and steady-state currents $(\square)$ because of perforation of the patch with gramicidin. Traces are averages of five sweeps. $C$, Time series of instantaneous current amplitudes during perforated patch formation. The calculated final access resistance was $59 \mathrm{M} \Omega$ in this experiment. $D$, Time series of the steady-state current. Note the continuous decrease from the initial values, which mainly indicate seal resistance, to the final values reflecting mainly input resistance. al., 1989). Patch pipettes were pulled from borosilicate glass (Garner Glass, Claremont, CA) and filled with (in $\mathrm{mM}$ ): $130 \mathrm{KCl}, 1 \mathrm{MgCl}_{2}, 0.07$ $\mathrm{CaCl}_{2}, 10 \mathrm{HEPES}$, and 0.1 EGTA ( $\mathrm{pH}$-adjusted to 7.3 with $\mathrm{KOH}$, osmolarity $300 \mathrm{mOsm})$. Gramicidin ( $5 \mathrm{mg} / \mathrm{ml}$ stock solution in DMSO) was added to the prefiltered patch solution to obtain a final concentration of $5 \mu \mathrm{g} / \mathrm{ml}$ and sonicated for $30 \mathrm{sec}$. Minimal pressure was applied to the patch pipette before cell contact. High resistance seals $(>0.8 \mathrm{G} \Omega)$ were obtained by application of negative pressure to the patch pipette, thus leading to the cell-attached configuration. Perforated patches with final access resistances $\sim 60-80 \mathrm{M} \Omega$ were obtained routinely after $10-20 \mathrm{~min}$ (Kyrozis and Reichling, 1995). Voltage-clamp experiments were performed with a List EPC7 amplifier (List, Darmstadt, Germany). Current traces were low-pass-filtered at $1-3 \mathrm{kHz}$ and digitized at $3 \mathrm{kHz}$ with a Labmaster TM-100 A/D converter (Scientific Solutions, Solon, OH) by use of the pClamp software (Axon Instruments, Foster City, CA). A liquid junction potential of $-1 \mathrm{mV}$ was left uncorrected. Pressure pulses (puffs; $5-8 \mathrm{kPa}$ ) of agonists were applied through a patch pipette connected to a solenoid-controlled pressure valve. Synaptic currents were elicited by focal application of constant voltage $(20-100 \mathrm{~V})$ pulses through a patch pipette $(2-3 \mathrm{M} \Omega$ ) filled with $150 \mathrm{~mm} \mathrm{NaCl}$.

Data analysis. Perforated patch access resistance was determined by analyzing the transient responses to voltage-clamp steps (Marty and Neher, 1995). The amplitude of the voltage step divided by the resultant instantaneous current yielded an estimate of series resistance. The small, incompletely compensated transient (see Fig. $1 A$ ) arising from electrode capacitance was ignored, and "instantaneous" current was measured 400 $\mu$ sec after the onset of the voltage step (Fig. $1 \mathrm{~A}, \mathbf{\square}$ ) or more commonly as the extrapolated zero time current obtained after fitting exponential decay curves to the current transients. In most cases the decay of the capacitive current transient could be well approximated by a single exponential. Estimates for access resistance obtained by dividing the resultant decay time constant by the whole-cell capacitance (Marty and Neher, 1995) were similar to those obtained with the instantaneous current methods. All membrane potentials subsequently were corrected for the voltage drop across the series resistance:

$$
V_{\text {corr }}=V_{\text {com }}-I_{\text {clamp }} \times R_{\mathrm{s}},
$$

in which $V_{\text {com }}$ is the command potential, $I_{\text {clamp }}$ is the clamp current, and $R_{\mathrm{S}}$ is the series resistance. Current-voltage $(I-V)$ relationships were obtained for the leak current (normally measured as the current amplitude $100 \mathrm{msec}$ before the evoked responses) and total current level at the peak of the evoked responses. Because the current levels differed for baseline versus evoked response conditions (see Fig. $2 A$, $\square$ vs $\square$ ), the corresponding values for $V_{\text {corr }}$ were different for each given value of $V_{\text {com }}$. Equilibrium potentials were determined by measuring the voltage at the intersection of the leak and total current $I-V$ curves. Data are presented as mean \pm SEM, and $n$ designates the number of cells.

Drugs. GABA, muscimol, and gramicidin were obtained from Sigma (St. Louis, MO); CGP 35348 was a gift from CIBA-Geigy (Basel, Switzerland). All other drugs were from Research Biochemicals (Natick, MA).

\section{RESULTS}

Perforated patch-clamp recordings were obtained from 46 thalamic cells (28 nRt cells and 18 relay cells). $\mathrm{nRt}$ and relay cells were identified under the microscope by their characteristic morphology and localization in the slice (nRt is bounded by the internal capsule and the external medullary lamina). A typical voltage-clamp recording from a nRt cell is shown in Figure 1. Soon after seal formation (Fig. $1 A$ ) the current transient was reflected mainly by the seal resistance, whereas after $8 \mathrm{~min}$ (Fig. $1 B)$ a perforated patch recording configuration was obtained. During this time period the instantaneous ( $\mathbf{\square}$, Fig. $1 A, C)$ and steady-state currents (Fig. $1 A, B, D, \square$ ) steadily increased and eventually reached plateau values (Fig. $1 C, D$ ). This is indicative of successful patch perforation by gramicidin, which forms cationselective pores through lipid membranes (Myers and Haydon, 1972). The calculated initial seal resistance in this experiment was $\sim 1 \mathrm{G} \Omega$ (Fig. $1 D, \mathbf{\square} ; 20 \mathrm{mV} / 21 \mathrm{pA}=0.95 \mathrm{G} \Omega$ ), and the steadystate access resistance was $\sim 60 \mathrm{M} \Omega$ (Fig. $1 D, \square ; 20 \mathrm{mV} / 340 \mathrm{pA}=$ $58.8 \mathrm{M} \Omega$ ). The mean access resistance, measured $10-15$ min after seal formation, in all experiments was $69 \pm 7 \mathrm{M} \Omega(n=40)$. The use of higher concentrations of gramicidin and/or patch pipettes with larger diameters severely interfered with successful seal formation in this preparation. Because $E_{\mathrm{Cl}}$ is a steady-state parameter, the relatively high access resistances were tolerable for the purposes of the present study. However, because current-induced voltage drops could be significant with these relatively large access resistances, voltage errors were compensated routinely in all experimental determinations of the chloride reversal potentials in this study (see Materials and Methods).

Examples of a perforated patch-clamp experiment in a nRt cell and a relay neuron are shown in Figure $2 A$ and $B$, respectively. In this and the following experiments, $\mathrm{GABA}_{\mathrm{B}}$ receptors were 

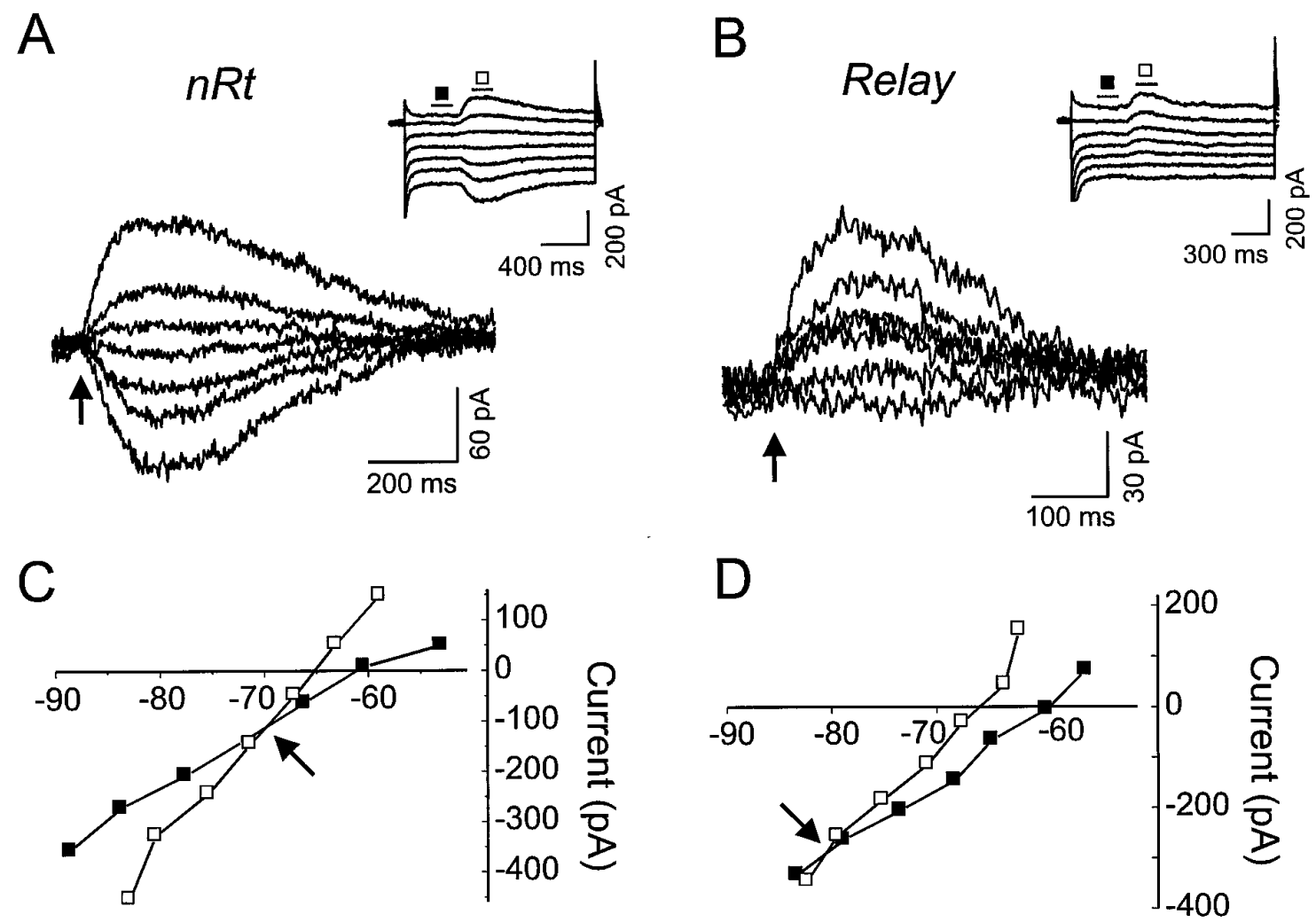

Membrane Potential (mV)

Membrane Potential (mV)

Figure 2. GABA-induced membrane currents at different command potentials $(-100$ to $-50 \mathrm{mV})$ obtained with gramicidin-filled patch pipettes from a nRt neuron $(A)$ and a relay cell $(B)$. GABA $(50 \mu \mathrm{M})$ was pressure-applied focally at the time point indicated by arrows. CGP $35348(0.5 \mathrm{mM})$ was present in the extracellular solution. Insets, Current amplitudes (pre-GABA, $\mathbf{\square}$, and GABA, $\square$ ) were measured at times indicated by horizontal bars. $C$, D, Current-voltage relationship of the leak current (pre-GABA, $\square$ ) and the total current during GABA application (GABA, $\square$ ) in the same cells as in $A$ and $B$. The reversal potentials (intersections of the two $I-V$ curves) are indicated by arrows and were $-70 \mathrm{mV}$ in $C$ and $-81 \mathrm{mV}$ in $D$.

blocked by including the selective antagonist $p$-(3-aminopropyl)p-diethoxymethyl-phosphinic acid (CGP 35348; $0.5 \mathrm{~mm}$ ) in the perfusion solution. GABA $(50 \mu \mathrm{M})$ was pressure-applied $(10-30$ msec, $0.1 \mathrm{~Hz}$ ) close to the soma of the voltage-clamped cells. The agonist-induced current was measured at different command potentials between -100 and $-50 \mathrm{mV}$. The amount of GABA applied was usually just above threshold for evoking a detectable current. GABA-evoked current always fully decayed within $<2$ sec (see Fig. 2). Conductance of the mean GABA response was $3.9 \pm 1.5 \mathrm{nS}(n=7)$ and $7.0 \pm 2.6 \mathrm{nS}(n=7)$ in $\mathrm{nRt}$ and relay cells, respectively (Fig. $2 C, D)$. Current-voltage $(I-V)$ relationships for current either before or during the GABA response revealed a reversal potential (arrows in Fig. $2 C, D$ ) that was more negative in relay than $\mathrm{nRt}$ cells. The mean $E_{\mathrm{GABA}}$ in $\mathrm{nRt}$ cells was $-71 \pm 2.5 \mathrm{mV}(n=12)$. This value was depolarized significantly, as compared with relay cells in which the mean $E_{\mathrm{GABA}}$ was $-81 \pm$ $2.6 \mathrm{mV}(n=9 ; p<0.02)$. Assuming a chloride activity coefficient of 0.76 for the extracellular electrolyte (Bormann et al., 1987), the calculated mean intracellular chloride activities in $\mathrm{nRt}$ and relay cells under these conditions were $5.4 \mathrm{~mm}$ and $3.8 \mathrm{~mm}$, respectively, assuming that $E_{\mathrm{GABA}}$ is determined mainly by the chloride gradient (see Discussion).

To ascertain that our estimates of $E_{\mathrm{GABA}}$ were not influenced by damage of the patch membrane, some experiments $(n=5)$ were performed in which the same cells was recorded both in perforated patch and whole-cell mode. Example GABA-evoked currents in a relay cell during perforated patch-clamp recordings are shown in Figure $3 A . E_{\mathrm{GABA}}$ in this experiment was $-87 \mathrm{mV}$ (Fig. $3 C$ ). After conventional whole-cell recording was established by rupturing the patch membrane with a vacuum pulse, $E_{\mathrm{GABA}}$ was determined again (Fig. $3 B, D$ ). In whole-cell mode $E_{\mathrm{GABA}}$ was approximately $-31 \mathrm{mV}$, presumably because of rapid diffusion of chloride from the pipette into the cytosol, as expected for small mobile ions (Pusch and Neher, 1988). We conclude that rupture of the perforated patch membrane would be easily detectable, because it immediately leads to a collapse of the chloride gradient (Kyrozis and Reichling, 1995).

In another set of experiments, the reversal potential of monosynaptic IPSCs was determined with perforated patch-clamp recordings. Inhibitory fibers were stimulated locally in the somatosensory thalamus by monopolar extracellular stimulation. Excitatory synaptic transmission was blocked with the selective ionotropic glutamate receptor antagonists ( \pm )2-amino-5phosphonopentanoic acid (APV; $50 \mu \mathrm{M}$ ) and 6-cyano-7nitroquinoxaline-2,3-dione (CNQX; $10 \mu \mathrm{M})$. In addition, $\mathrm{GABA}_{\mathrm{B}}$ receptor-mediated IPSPs were blocked with CGP 35348. We previously have shown that under such recording conditions evoked IPSCs in the somatosensory thalamus are mediated by $\mathrm{GABA}_{\mathrm{A}}$ receptors (Ulrich and Huguenard, 1995). Figure $4 A$ shows an evoked IPSC at different holding potentials during a perforated patch-clamp experiment in a relay cell. Figure $4 B$ shows the $I-V$ relationship of the total current during IPSCs and the leak current. The mean $E_{\text {IPSC }}$ in relay cells was $-82 \pm 4.4 \mathrm{mV}$ $(n=5)$, thus not significantly different from the equilibrium 

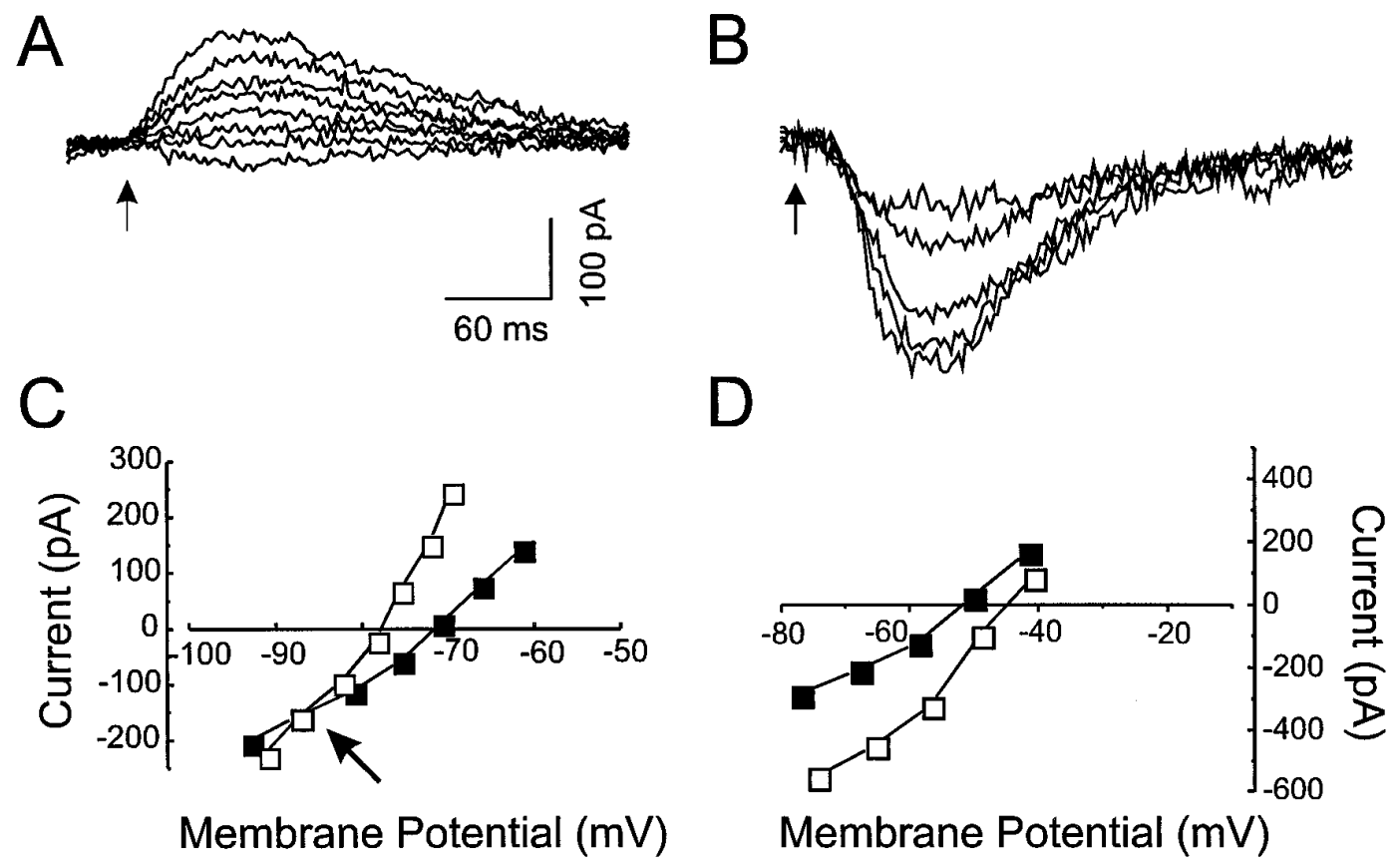

Figure 3. $A, B$, Perforated patch-clamp recording from a relay cell before $(A)$ and after $(B)$ rupturing the patch in the presence of CGP $35348(0.5$ mM). GABA $(50 \mu \mathrm{M})$ was pressure-applied focally at time points indicated by arrows. $C, D$, Current-voltage relationship of leak ( $\square)$ and agonist-induced ( $\square$ ) membrane currents in $A$ and $B$. Note the dramatic increase in current amplitudes and shift of the reversal potential after establishing conventional whole-cell recordings $(A$ vs $B)$. The reversal potential in $C$ was $-87 \mathrm{mV}$, and the extrapolated $E_{\mathrm{GABA}}$ in $D$ was $-31 \mathrm{mV}$.

potential obtained by GABA application in the same cell type. This indicates that the synaptically and agonist-activated membrane conductances have similar ion selectivities and that chloride loading because of ion influx is negligible in these experiments (Thompson and Gähwiler, 1989).

IPSCs could not be detected in nRt cells at various holding potentials (between -90 and $-50 \mathrm{mV}$ ) with perforated patch recordings in the present study $(n=13)$ either with glutamate application or electrical stimulation, even under conditions in which synaptic release should be enhanced, such as high $\left[\mathrm{K}^{+}\right]_{\mathrm{o}}$ or with $0.1 \mathrm{~mm}$ 4-aminopyridine added to the bath. However, evoked and miniature spontaneous IPSCs previously have been recorded in the same preparation with whole-cell techniques with cesiumfilled cells, where the holding potential could be set to $0 \mathrm{mV}$ and the resultant driving force was approximately $+60 \mathrm{mV}$ (Ulrich and Huguenard, 1995, 1996). The absence of detectable IPSCs in $\mathrm{nRt}$ cells in the current perforated patch experiments was probably attributable to two factors. First, the maximum driving force $( \pm 20 \mathrm{mV}$ ) that could be attained was relatively small, and second, the relatively high access resistances of the perforated patch electrodes resulted in a decreased frequency response of the patch-clamp amplifier and, therefore, a reduced ability to record rapid and small synaptic events.

Active chloride extrusion mechanisms maintain a low intracellular chloride concentration in mammalian CNS neurons (Misgeld et al., 1986; Thompson et al., 1988a,b; Inoue et al., 1991). To investigate whether such transport is involved in maintaining $E_{\mathrm{Cl}}$ in thalamic cells, we investigated the effects of furosemide, a chloride cation cotransport blocker (for review, see Haas, 1989). Figure 5 shows GABA-induced membrane currents at different holding potentials obtained from a relay cell with perforated patch-clamp recordings under control conditions (Fig. $5 A$ ) and after bath application of furosemide $(1 \mathrm{~mm}$; Fig. $5 B)$. Figure $5 C, D$

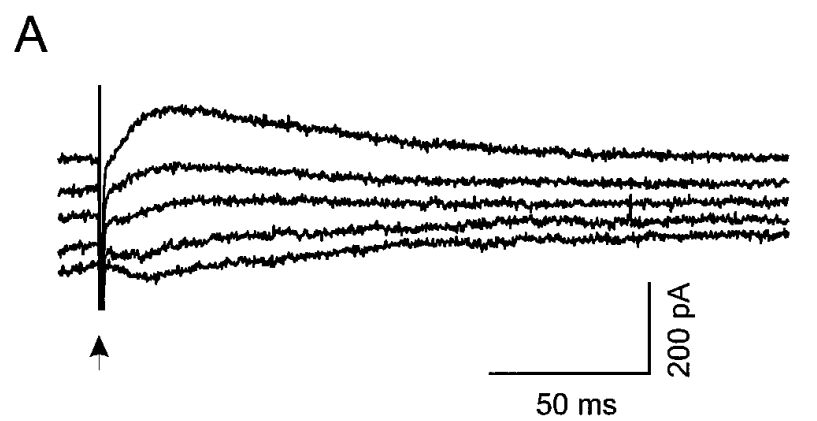

B

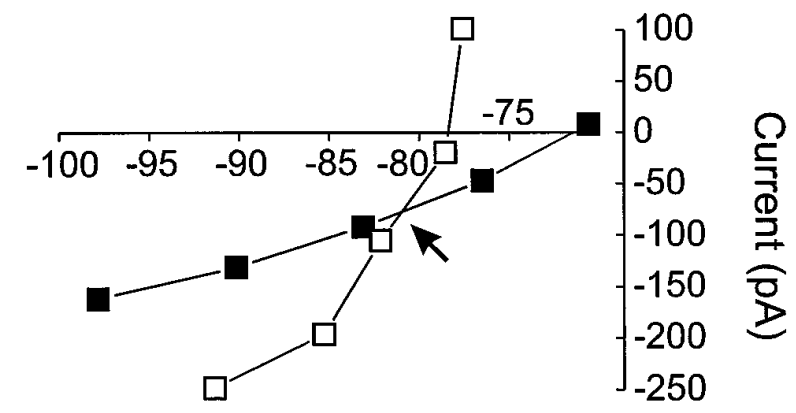

\section{Membrane Potential (mV)}

Figure 4. A monosynaptically evoked IPSC recorded in a relay cell during a perforated patch-clamp experiment is shown in $A$ at different command potentials $(-100 \mathrm{mV}$ to $-70 \mathrm{mV})$. Excitatory synaptic transmission was blocked with CNQX and APV, and GABA ${ }_{B}$ IPSCs were blocked with CGP 35348. The stimulus artifact is partially truncated for clarity. $B$, Current-voltage relationship of the total current during the IPSC ( $\square$ ) and the pre-IPSP current (ם) intersect at $-81 \mathrm{mV}$, as indicated by an arrow. 

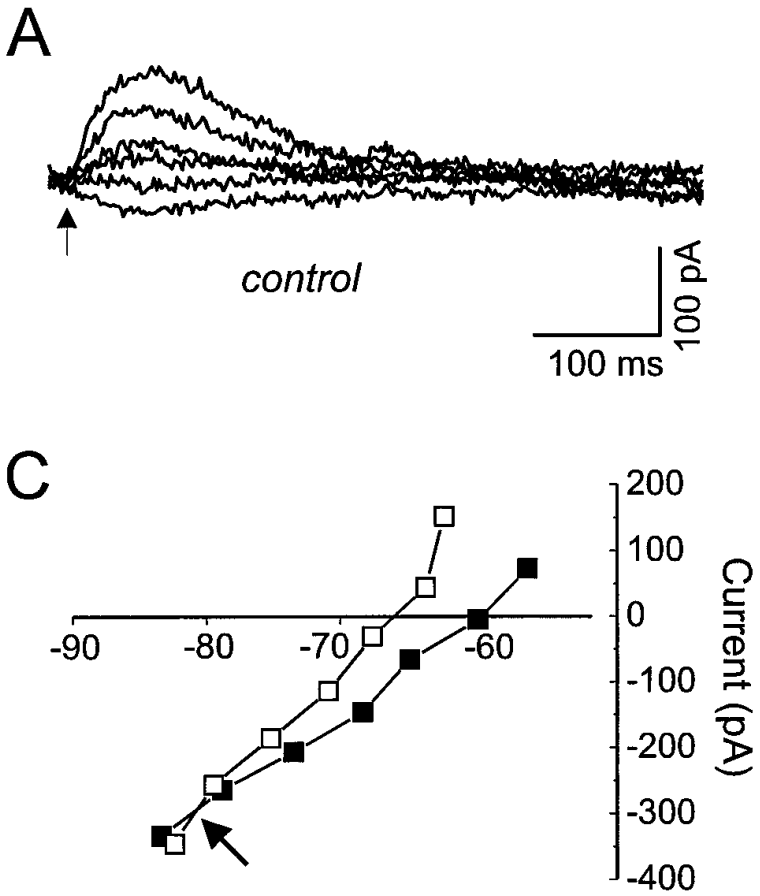

Membrane Potential (mV)
$\mathrm{B}$

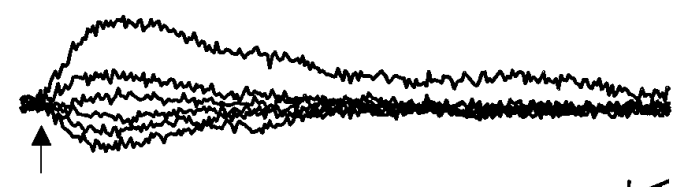

furosemide

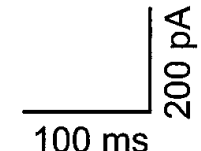

D

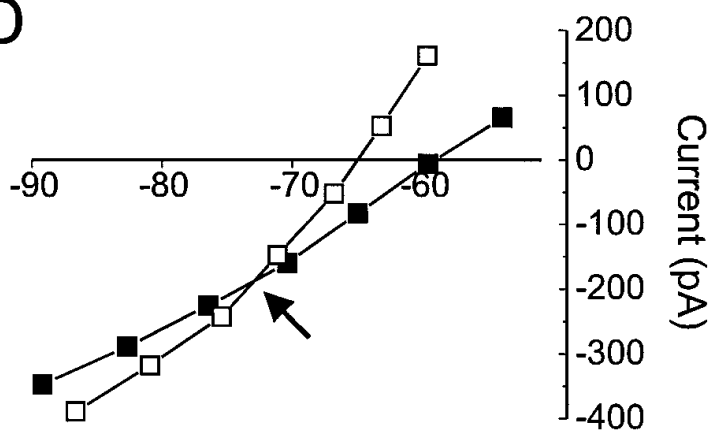

Membrane Potential (mV)

Figure 5. GABA-induced membrane current at different holding potentials in a relay cell in control $(A)$ and after bath application of the chloride transport blocker furosemide $(B ; 1 \mathrm{mM})$. GABA $(50 \mu \mathrm{M})$ was applied focally at time points indicated by arrows. $C, D$, Current-voltage relationship of leak $(\square)$ and total (GABA + leak; $\square)$ currents in control condition $(C)$ and after furosemide application $(D)$. Note the shift of current cross-points $($ arrows $)$ after furosemide application, indicating a depolarizing shift of $E_{\mathrm{GABA}}$.

shows the corresponding $I-V$ curves for leak and GABA current under the two different recording conditions. In six thalamic cells tested ( 3 relay and $3 \mathrm{nRt}$ ) furosemide decreased the chloride reversal potential on average by $9 \pm 1.5$ and $7 \pm 0.9 \mathrm{mV}$, respectively. A partial recovery was obtained in four cells. In the two remaining experiments, cells were lost before washout was completed. From these data we conclude that thalamic cells maintain a low intracellular chloride concentration by an active chloride extrusion mechanism.

\section{DISCUSSION}

The aim of the present study was to determine the reversal potential of GABA-induced currents in the two principal cell types of the somatosensory thalamus, i.e., thalamocortical relay cells and inhibitory neurons of the nucleus reticularis thalami, by means of perforated patch-clamp techniques. We found that the reversal potential of GABA currents or $\mathrm{GABA}_{\mathrm{A}}$ receptormediated IPSCs was hyperpolarized significantly more in relay, as compared with nRt, cells. In addition, our experiments suggest that both cell types maintain a low intracellular chloride activity via active transport processes.

Previous attempts to estimate intracellular chloride activities in thalamic and other CNS neurons were hampered by the invasiveness of the methods applied. Microelectrode, conventional wholecell, and perforated patch-clamp recordings using the chloridepermeable ionophores nystatin and amphotericin B all can influence the chloride reversal potential by altering the intracellular ion activities to some degree (Rhee et al., 1994; Kyrozis and Reichling, 1995). However, the pore-forming antibiotic gramicidin is poorly permeable to anions (Myers and Haydon, 1972) and therefore does not alter the chloride distribution across the cell membrane. Nevertheless, our values of $E_{\mathrm{GABA}}$ in relay and $\mathrm{nRt}$ cells are in agreement with previous estimates (Bal and McCormick, 1993; Huguenard and Prince, 1994a) but more hyperpolarized than other studies in nRt cells (McCormick and Prince, 1986; Spreafico et al., 1988). We have shown that $E_{\mathrm{IPSP}}=E_{\mathrm{GABA}}$ in relay cells, which indicates that there was no shift in $E_{\mathrm{Cl}}$ because of chloride influx during GABA application. The high chloride selectivity of the $\mathrm{GABA}_{\mathrm{A}}$ channel in mammalian CNS neurons toward the other main physiological electrolytes (Bormann et al., 1987 ) justifies the approximation $E_{\mathrm{GABA}} \approx E_{\mathrm{Cl}}$. Our estimates of intracellular chloride activities are somewhat lower than results obtained with the same method in cultured cells of substantia nigra (Ebihara et al., 1995) and nucleus tractus solitarii (Rhee et al., 1994) but close to $E_{\mathrm{Cl}}$ measured in hippocampal cells with optical methods (Inoue et al., 1991). As in hippocampus (Misgeld et al., 1986), our study supports the finding that different cell types in the CNS maintain a slightly different intracellular chloride homeostasis. If as in neocortex (Kaila et al., 1993) and hippocampus (Staley et al., 1995) bicarbonate permeation contributes to $\mathrm{GABA}_{\mathrm{A}}$ receptor-mediated responses in thalamus, then our estimates of intracellular $\mathrm{Cl}$ activities $(<6 \mathrm{~mm})$ actually would be overestimates. Prolonged chloride influx can lead to a decrease in the chloride driving force because of intracellular chloride accumulation (Huguenard and Alger, 1986; Thompson and Gähwiler, 1989). Chloride loading may explain partially why some previous studies have found more depolarized values for $E_{\mathrm{GABA}}$ in $\mathrm{nRt}$ cells (McCormick and Prince, 1986; Spreafico et al., 1988).

Low intracellular ion activities suggest active membrane trans- 
port mechanisms. Indeed, it previously has been shown that chloride is extruded actively from pyramidal cells by a furosemidesensitive cation/chloride cotransporter (Misgeld et al., 1986; Thompson et al., 1988a,b). A similar mechanism has been postulated for thalamic relay cells after observing abnormal shifts of $E_{\mathrm{GABA}}$ during whole-cell recordings (Huguenard and Prince, $1994 a)$. Here, we found a reversible decrease in $E_{\mathrm{GABA}}$ in both thalamic cell types after exposure to furosemide. It can, therefore, be suggested that active chloride extrusion mechanisms exist in thalamic and reticular neurons as well. However, the contributions of additional transport systems such as ATP-ases (Inoue et al., 1991) have not been investigated in the present study but are suggested by the fact that in a few cases (1 relay and $3 \mathrm{nRt}$ cells), especially after furosemide treatment, we found $E_{\mathrm{GABA}}$ slightly depolarized from rest. This may be explained by additional inward chloride transport and/or bicarbonate efflux (Misgeld et al., 1986; Staley et al., 1995).

The mean resting potentials of relay cells and $\mathrm{nRt}$ cells in this in vitro preparation, averaged over a large number of cells, are -71 and $-73 \mathrm{mV}$, respectively (Huguenard and Prince, 1994a; Cox et al., 1995). Therefore, there exists a substantial driving force of $10 \mathrm{mV}$ for chloride in relay cells. The combination of more negative $E_{\text {GABA-A }}$ (this study) and larger inhibitory synaptic conductance (Ulrich and Huguenard, 1995, 1996) explains the more prominent IPSPs recorded in relay cells than in $\mathrm{nRt}$ cells (von Krosigk et al., 1993; Huguenard and Prince, 1994a; Bal et al., 1995a). Significant hyperpolarization is necessary to remove inactivation from T-type calcium channels (Coulter et al., 1989; Huguenard and Prince, 1992). A hyperpolarized $E_{\mathrm{GABA}}$ seems to be necessary to generate rebound bursts in relay cells, a characteristic of thalamic spindle oscillations (von Krosigk et al., 1993). On the other hand, in nRt cells there seems to be almost no net driving force for chloride ions. This suggests that intra-nRt inhibition mediated by $\mathrm{GABA}_{\mathrm{A}}$ receptors essentially is shunting. Therefore, one of the prerequisites for autonomous intra-nRt oscillations as derived from computer models (Golomb et al., 1994) is not met in our preparation. This may explain why an intact excitatory-inhibitory circuitry is necessary to sustain oscillatory activities in this and similar preparations (von Krosigk et al., 1993). However, mutual inhibition within nRt may, nevertheless, have functional consequences, because focal application of the $\mathrm{GABA}_{\mathrm{A}}$ receptor antagonist bicuculline to nRt can lead to an enhanced output from this nucleus (von Krosigk et al., 1993; Huguenard and Prince, 1994b). Further, bath application of bicuculline leads to a prolongation of burst duration in $\mathrm{nRt}$ cells during phasic network activity (Bal et al., 1995b). This suggests that $\mathrm{GABA}_{\mathrm{A}}$ receptor-mediated intra-nRt connections can evoke inhibitory mechanisms sufficiently powerful to truncate calcium-dependent burst mechanisms (Ahlsén and Lindström, 1982).

\section{REFERENCES}

Ahlsén G, Lindström S (1982) Mutual inhibition between perigeniculate neurones. Brain Res 236:482-486.

Bal T, McCormick DA (1993) Mechanism of oscillatory activity in guinea-pig nucleus reticularis thalami in vitro: a mammalian pacemaker. J Physiol (Lond) 468:669-691.

Bal T, von Krosigk M, McCormick DA (1995a) Synaptic and membrane mechanisms underlying synchronized oscillations in the ferret lateral geniculate nucleus in vitro. J Physiol (Lond) 483:641-663.

Bal T, von Krosigk M, McCormick DA (1995b) Role of ferret perigeniculate nucleus in the generation of synchronized oscillations in vitro. J Physiol (Lond) 483:665-685.

Bormann J, Hamill OP, Sakmann B (1987) Mechanism of anion perme- ation through channels gated by glycine and $\gamma$-aminobutyric acid in mouse cultured spinal neurones. J Physiol (Lond) 385:243-286.

Coulter DA, Huguenard JR, Prince DA (1989) Calcium currents in rat thalamocortical relay neurones: kinetic properties of the transient, low-threshold current. J Physiol (Lond) 414:587-604.

Cox CL, Huguenard JR, Prince DA (1995) Cholecystokinin depolarizes rat thalamic reticular neurons by suppressing a $\mathrm{K}^{+}$conductance. J Neurophysiol 74:990-1000.

Cox CL, Huguenard JR, Prince DA (1996) Heterogeneous axonal arborizations of rat thalamic reticular neurons in the ventrobasal nucleus. J Comp Neurol 366:416-430.

Crunelli V, Haby M, Jassik-Gerschenfeld D, Leresche N, Pirchio M (1988) $\mathrm{Cl}^{-}$and $\mathrm{K}^{+}$-dependent inhibitory postsynaptic potentials evoked by interneurones of the rat lateral geniculate nucleus. J Physiol (Lond) 399:153-176.

Deschênes M, Madariaga-Domich A, Steriade M (1985) Dendrodendritic synapses in the cat reticularis thalami nucleus: a structural basis for thalamic spindle synchronization. Brain Res 334:165-168.

Ebihara S, Shirato K, Harata N, Akaike N (1995) Gramicidin-perforated patch recording: GABA response in mammalian neurones with intact cellular chloride. J Neurophysiol 484:77-86.

Golomb DA, Wang XJ, Rinzel J (1994) Synchronization properties of spindle oscillations in a thalamic reticular nucleus model. J Neurophysiol 72:1109-1126.

Haas M (1989) Properties and diversity of (Na-K-Cl) cotransporters. Annu Rev Physiol 51:443-457.

Huguenard JR, Alger BE (1986) Whole-cell voltage-clamp study of the fading of GABA-activated currents in acutely dissociated hippocampal neurons. J Neurophysiol 56:1-18.

Huguenard JR, Prince DA (1992) A novel T-type current underlies prolonged $\mathrm{Ca}^{2+}$-dependent burst firing in GABAergic neurons of rat thalamic reticular nucleus. J Neurosci 12:3804-3817.

Huguenard JR, Prince DA (1994a) Intrathalamic rhythmicity studied in vitro: nominal T-current modulation causes robust antioscillatory effects. J Neurosci 14:5485-5502.

Huguenard JR, Prince DA (1994b) Clonazepam suppresses $\mathrm{GABA}_{\mathrm{B}^{-}}$ mediated inhibition in thalamic relay neurons through effects in nucleus reticularis. J Neurophysiol 71:2576-2581.

Inoue M, Hara M, Zeng XT, Hirose T, Onishi S, Yasukura T, Uriu T, Omori K, Minato A, Inagaki C (1991) An ATP-driven $\mathrm{Cl}^{-}$pump regulates $\mathrm{Cl}^{-}$concentrations in rat hippocampal neurons. Neurosci Lett 134:75-78.

Kaila K, Voipio J, Paalasmaa P, Pasternack M, Deisz RA (1993) The role of bicarbonate in $\mathrm{GABA}_{\mathrm{A}}$ receptor-mediated IPSPs of rat neocortical neurones. J Physiol (Lond) 464:273-289.

Kyrozis A, Reichling DB (1995) Perforated patch recording with gramicidin avoids artifactual changes in intracellular chloride concentration. J Neurosci Methods 57:27-35.

Marty A, Neher E (1995) Tight-seal whole-cell recording. In: Singlechannel recording (Sakmann B, Neher E, eds), pp 31-52. New York: Plenum.

McCormick DA, Prince DA (1986) Acetylcholine induces burst firing in thalamic reticular neurones by activating a potassium conductance. Nature 319:402-405.

Misgeld U, Deisz RA, Dodt HU, Lux HD (1986) The role of chloride transport in postsynaptic inhibition of hippocampal neurons. Science 232:1413-1415.

Myers VB, Haydon DA (1972) Ion transfer across lipid membranes in the presence of gramicidin A. II. The ion selectivity. Biochim Biophys Acta 274:313-322.

Pusch M, Neher E (1988) Rates of diffusional exchange between small cells and a measuring patch pipette. Pflügers Arch 411:204-211.

Rhee JS, Ebihara S, Akaike N (1994) Gramicidin-perforated patchclamp technique reveals glycine-gated outward chloride current in dissociated nucleus solitarii neurons of the rat. J Neurophysiol 72:1103-1108.

Sakmann B, Edwards F, Konnerth A, Takahashi T (1989) Patch-clamp techniques for studying synaptic transmission in slices of mammalian brain. Q J Exp Physiol 74:1107-1118.

Spreafico R, De Curtis M, Frassoni C, Avanzini G (1988) Electrophysiological characteristics of morphologically identified reticular thalamic neurons from rat slices. Neuroscience 27:629-638.

Staley KJ, Soldo BL, Proctor WR (1995) Ionic mechanisms of neuronal excitation by inhibitory GABA $_{A}$ receptors. Science 269:977-981.

Steriade M, Domich L, Oakson G, Deschênes M (1987) The deaffer- 
ented reticular thalamic nucleus generates spindle rhythmicity. J Neurophysiol 57:260-273.

Steriade M, McCormick DA, Sejnowski TJ (1993) Thalamocortical oscillations in the sleeping and aroused brain. Science 262:679-685.

Thompson SM, Gähwiler BH (1989) Activity-dependent disinhibition. III. Desensitization and $\mathrm{GABA}_{\mathrm{B}}$ receptor-mediated presynaptic inhibition in the hippocampus in vitro. J Neurophysiol 61:524-533.

Thompson SM, Deisz RA, Prince DA (1988a) Relative contributions of passive equilibrium and active transport to the distribution of chloride in mammalian cortical neurons. J Neurophysiol 60:105-124.

Thompson SM, Deisz RA, Prince DA (1988b) Outward chloride/cation co-transport in mammalian cortical neurons. Neurosci Lett 89:49-54.
Ulrich D, Huguenard JR (1995) Purinergic inhibition of GABA and glutamate release in the thalamus: implications for thalamic network activity. Neuron 15:909-918.

Ulrich D, Huguenard JR (1996) GABA $_{\mathrm{B}}$ receptor-mediated responses in GABA-ergic projection neurones of rat nucleus reticularis thalami in vitro. J Physiol (Lond) 493:845.

von Krosigk M, Bal T, McCormick DA (1993) Cellular mechanisms of a synchronized oscillation in the thalamus. Science 261:361-364.

Williamson AM, Ohara PT, Ralston DD, Milroy AM, Ralston III HJ (1994) Analysis of gamma-aminobutyricacidergic synaptic contacts in the thalamic reticular nucleus of the monkey. J Comp Neurol 349:182-192. 